\title{
POTENTIAL NEUROPROTECTIVE THERAPIES IN TRAUMATIC ACUTE SPINAL INJURY: AN INTEGRATIVE REVIEW
}

\author{
Lucas Faria Rodrigues; ; Júlia Sobottka de Mathias Fernandes ${ }^{\mathbf{1}}$; Bianca Rodrigues

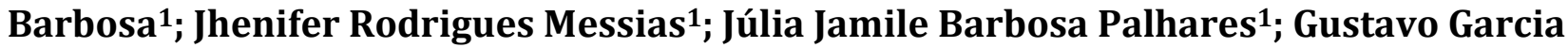 \\ Pacheco $^{1}$ and Eduardo Guerra Barbosa Sandoval ${ }^{2}$
}

\author{
${ }^{1}$ Medical students at the Universidade de Franca (UNIFRAN) - Franca - SP - Brazil \\ ${ }^{2}$ Master teacher supervisor Eduardo Guerra Barbosa Sandoval at the Universidade de Franca (UNIFRAN) - \\ Franca - SP - Brazil
}

\section{ARTICLE INFO}

Article History:

Received $15^{\text {th }}$ August, 2021

Received in revised form

$16^{\text {th }}$ September, 2021

Accepted $10^{\text {th }}$ October, 2021

Published online $28^{\text {th }}$ November, 2021

\section{Key Words:}

Spinal cord injury;

Spinal cord trauma; Neuroprotectors;

Drug therapy;

*Corresponding author:

Lucas Faria Rodrigues

\begin{abstract}
Introduction: Acute traumatic spinal cord injury is a complex injury affecting the nervous tissue of the spinal cord, vertebrae, joints, innervation and local vasculature, resulting in high mortality, physical dependence, stress, financial losses, lifelong risk of medical complications and reduced longevity. The complexity of the clinical repercussions of acute spinal cord trauma (SCI) makes early interventions necessary to ensure better prognosis. Emerging therapies with neuroprotective agents emerge ${ }^{1,2,3}$ Methodology: For the integrative literature review, the PubMed databases were used, Scielo, Google Scholar, Cochrane and the descriptors "spinal injury"; "spinal cord trauma"; "neuroprotective" and "drug therapy". Results: Therapies with corticosteroids, ion channel blockers, agonists and antagonists of neurotransmitters, cellular and genetic agents, vitamin D, progesterone, erythropoietin and caspase inhibitors demonstrated different neuroprotective effects involving reduction of secondary spinal cord injury and acceleration of neuronal recovery. in uneven research phases. Conclusion: It is concluded that preclinical studies with neuroprotectors as a potential treatment for TRM are promising, however, not all of them evolve into clinical trials, which limits the application of these therapies in humans. Therefore, it is necessary to improve research and clinical trials related to the use of neuroprotective agents in the management of traumatic acute spinal cord injury.
\end{abstract}

Copyright (C) 2021, Lucas Faria Rodrigues et al. This is an open access article distributed under the Creative Commons Attribution License, which permits unrestricted use, distribution, and reproduction in any medium, provided the original work is properly cited.

Citation: Lucas Faria Rodrigues, Júlia Sobottka de Mathias Fernandes, Bianca Rodrigues Barbosa, Jhenifer Rodrigues Messias, Júlia Jamile Barbosa Palhares, Gustavo Garcia Pacheco and Eduardo Guerra Barbosa Sandoval. "Potential neuroprotective therapies in traumatic acute spinal injury: an integrative review", International Journal of Development Research, 11, (11), 51919-51923.

\section{INTRODUCTION}

Acute spinal cord injury of traumatic origin or spinal cord trauma (SCI) is a complex injury that affects the nervous tissue of the spinal cord, which can also affect vertebrae, joints, innervation and local vasculature, resulting in high mortality rates or serious sequelae that generate physical dependence, psychological stress, financial losses, significantly increased risk of lifelong medical complications and reduced life expectancy. ${ }^{1}$ More than $50 \%$ of patients who suffer a traumatic spinal cord injury may not recover their normal function and the population most commonly affected are healthy young people between 15 and 25 years. Data from Canada indicate that the total lifetime costs of a patient with a spinal cord injury exceeds $\$ 3$ million. In Brazil, in 2002, the number of deaths from trauma represented $9 \%$ of deaths, corresponding to more than five million deceased victims of trauma in the country.
The complexity of the clinical repercussions of acute spinal cord injury in the short and long term in the lives of patients demonstrates the need to obtain quality early interventions that guarantee a better prognosis. ${ }^{1,2,3}$ The initial phase of TRM occurs immediately after the injury and is classified as a primary injury, involving destruction of the neural parenchyma, rupture of the axonal network and glial membrane, in addition to damage to the vasculature with extravasation of red blood cells and leukocytes. From it, a cascade of chemical and mechanical events develops, triggering secondary damage. The extravasation of immune cells at the site of injury creates increased pressure on spinal tissues and produces vasospasms, leading to further interruption of local blood flow. Consequently, neuronal ischemia and inflammation caused by the penetration of immune cells and inflammatory cytokines into spinal tissues result in vasogenic edema that culminates in cell death and tissue necrosis. All of these processes lead to free radical formation and excitotoxicity through excessive release and impaired glutamate uptake, which 
contributes to nerve tissue degradation. In addition, high levels of glutamate in necrotic cells disrupt ionic homeostasis by increasing intracellular concentrations of $\mathrm{Na}^{+}$and $\mathrm{Ca}^{2+}$, which causes an imbalance in the ion flow, and ultimately, generates mitochondrial dysfunction, cytotoxic edema and increased release of reactive oxygen species. ${ }^{2,3} \mathrm{New}$ strategies for early intervention in acute spinal cord injuries of traumatic origin have been studied, seeking to improve the clinical evolution and prognosis of these patients. This fact is possible through the reduction of neural damage and the promotion of motor recovery. Among these strategies, emerging therapies with neuroprotective agents are highlighted, which aim to reduce the impacts of secondary spinal cord injury on nervous tissue. $^{3}$

\section{METHODOLOGY}

This study is an integrative literature review, which aims to analyze the use of neuroprotective agents in the acute phase of traumatic spinal cord injury. During the research for the development of the integrative literature review, the databases PubMed, SCIelo, Google Scholar and Cochrane and the descriptors "spinal injury" were used; "spinal cord trauma"; "neuroprotective"; "drug therapy". Thus, from reading the abstracts, articles published in the last 30 years that contained analyzes on neuroprotective agents applied in the acute phase of spinal cord trauma were selected. Thus, more than twenty articles were reviewed, ranging from experimental studies in animals, clinical trials in humans and literature reviews. The analysis of the results is summarized in table 1 . The selected studies supported the review of the following neuroprotective agents, their mechanisms of action and clinical applications: corticosteroids, $\mathrm{Ca}^{2+}$ channel blockers, $\mathrm{Na}^{+}$channel blockers, agonists and antagonists of neurotransmitters, cellular and genetic agents, vitamin D and progesterone, erythropoietin caspase inhibitors.

\section{RESULTS AND DISCUSSION}

Corticosteroids: Corticosteroids are the most widely studied neuroprotective agents in the initial treatment of TRM. In addition, methylprednisolone (MP), the best-studied representative within this category, has been used in clinical practice for years. It is understood that its action as a neuroprotector occurs through several mechanisms: reduction in the formation of free radicals and oxidative degradation of lipids, inhibition of ischemia, stimulation of aerobic metabolism, it is worth mentioning. ${ }^{24} \mathrm{~A}$ systematic review, after analyzing multiple clinical trials on the action of MP as a neuroprotector in TRM, concluded that its use is indicated during the first 48 hours when its administration occurs between 3 and 8 hours after the injury. However, the same study highlights the increased risk of infections when using MP. $6,7,8$

$\mathrm{Ca}^{2+}$ and $\mathrm{Na}{ }^{+}$channel blockers: Prolonged excitation due to excessive release and inadequate reuptake of glutamate in the secondary lesion promotes an accentuated influx of calcium and sodium by activating metabotropic and ionotropic receptors and by calcium entry through voltage-dependent calcium channels, opened with membrane depolarization. The exaggerated calcium ion influx into the mitochondria contributes to the activation of the cell apoptosis cascade through the generation of reactive oxygen species, mitochondrial edema and the release of apoptogenic factors that activate caspases that execute programmed cell death. Research has shown that calcium channel blocking drugs are promising neuroprotective agents by preventing the exacerbated influx of this ion and preventing the progression of secondary lesions. ${ }^{9}$ Nimodipino is a calcium channel blocker that acts on L-type channels preventing calcium-dependent activation of apoptotic enzymes and blocks presynaptic glutamate release. It has shown efficacy in animal experiments, with improved blood flow and neurological recoveries, but clinical trials Nimodipino versus placebo did not show differences in motor recoveries after spinal cord injury, so evidence does not recommend its clinical use in patients with spinal cord injury. ${ }^{3.10}$
Dantrolene is an endoplasmic reticulum ryanodine receptor blocker that inhibits the release of intracellular calcium stores. Its neuroprotection has so far been demonstrated in ex vivo, in vivo and in vitro studies, but there are still few works related to its use in acute spinal cord injury. An in vivo animal study evaluated the neurological evolution of rats submitted to acute spinal cord injury, demonstrating that the group using isolated dantrolene was the only one that showed functional neurological recovery in the incline stationary stationary test, suggesting a possible action of this drug in motor and sensory pathways, in addition to presenting recovery of pain sensitivity and clearly visible movements in the pelvic limbs, without weight support, in a few days, demonstrating clinical improvement far superior to animals using placebo within the same time interval. " $\mathrm{Na}$ channel blockers perform neuroprotection by slowing down the mechanisms of cellular edema, ATP loss and also by improving membrane integrity. Within this category, the neuroprotective effect of Riluzole is based on decreasing sodium and calcium efflux and hydrogen influx in the presynaptic neuron, so that there is no stimulus for the extracellular release of glutamate from them. Then, in postsynaptic neurons, blocking the influx of sodium and calcium by NMDA (N-Methyl-D-aspartate) and AMPA (alphaamino-3-hydroxy-5-methyl-4-isoxazol-propionic acid channels)) prevents cell death and axonal edema. It has a high avidity for plasma proteins such as albumin and lipoproteins. Metabolized in the liver by the cytochrome P450 enzyme. ${ }^{2.12}$ Currently, in a randomized controlled clinical study in humans, it is evaluating the efficacy and safety of this drug in patients with acute spinal cord injury. Its latest result, carried out in 2018, showed that riluzole improved the patients' motor and sensory functions. However, studies have also shown important adverse reactions such as pancreatitis, hepatotoxicity, lung disease and neutropenia. Thus, the drug still needs to be evaluated in terms of dose and time of use for maximum benefit in selected patients. ${ }^{13.14 .15}$

Neurotransmitter agonists/antagonists: Alpha 2-adrenergic agonists and antagonists (A2a) are neuroprotective drugs that have different actions, but with the same objective of helping in the recovery of spinal cord injury. While A2a antagonists inhibit excitotoxicity by decreasing the emission of neurotransmitters in the body, A2a agonists improve motor function and cell viability, which allows avoiding the neurological loss that occurs after TRM. ${ }^{\text {wo }}$ In tests carried out in rabbits and mice, the potentiation of motor function, neuronal viability and the deceleration of tissue damage by neuronal apoptosis were proven with the use of adenosine A2a receptor agonist. From this, it was also realized that by controlling the A1 and A2 adenosine receptors, it would modulate pro-inflammatory signals and responses, which with drugs, such as caffeine, that block these receptors, there would then be neuroprotection against loss of locomotor function and tissue damage. As for $\mathrm{Aa} 2$ antagonists, ionotropic glutamate receptors undergo adjustments on the intracellular entry of $\mathrm{K}^{+}, \mathrm{Na}{ }^{+}$and $\mathrm{Ca}^{2+}$ when activated by NMDA, AMPA and Kainate antagonists. This is done because at high concentrations, glutamate can lead to excitotoxicity to uninjured neurons and NMDA, AMPA and kainate help to treat this harmful effect. These antagonists are also able to inhibit hypoxia, necrosis and also contribute to the control of secondary lesions. ${ }^{\text {wo }}$

Cellular and genetic agents: Cellular and genetic neuroprotective agents aim at the functional recovery of spinal nerve cells, this therapeutic approach includes growth factors such as brain-derived neurotrophic factor (BDNF) and transforming growth factor- $\beta$ (TGF$\beta)$. BDNF is a therapy in clinical phase that acts as a modulator of synaptic plasticity of the central and peripheral nervous system, in addition to regulating excitatory neurotransmitters, reducing oxidative stress and promoting neuroprotection, functional recovery and neuronal survival. TGF- $\beta$ is the factor responsible for elevating the immune response, inducing scarring and glial, thus acting in the functional recovery of the brain. in migration, neuronal differentiation and neuroprotection. ${ }^{\text {wo }}$ Innovative therapies are being carried out with stem cells, whether neural, medullary, olfactory and Schwann cells, this therapeutic group has a wide range of activities since it acts both 
Table 1. Analysis of studies on the use of neuroprotective therapies in the management of acute spinal cord injury of traumatic origin

\begin{tabular}{|c|c|c|c|}
\hline AUTHOR / TITLE / YEAR & KIND OF STUDY & GOAL & CONCLUSION \\
\hline $\begin{array}{l}\text { Joaquim AF, Daniel JW, Schroeder GD, Vaccaro AR/ Neuroprotective } \\
\text { Agents as an Adjuvant Treatment in Patients With Acute Spinal Cord } \\
\text { Injuries: A Qualitative Systematic Review of Randomized Trials/ } 2020\end{array}$ & Literature review & $\begin{array}{l}\text { Analyze randomized clinical trials that guide } \\
\text { neuroprotective agents as potential optimizers of the } \\
\text { outcome of patients with SCI. }\end{array}$ & $\begin{array}{l}\text { Only methylprednisolone, vitamin D plus progesterone, and } \\
\text { erythropoietin improved patient outcome. However, the } \\
\text { benefits were modest. }\end{array}$ \\
\hline $\begin{array}{l}\text { Bracken MB, Shepard MJ, Collins WF, Holford TR, Young W, Baskin } \\
\text { DS, et al./ A randomized, controlled trial of methylprednisolone or } \\
\text { naloxone in the treatment of acute spinal-cord injury/ } 1990\end{array}$ & randomized clinical trial & $\begin{array}{l}\text { Evaluate the efficacy of Methylprednisolone therapy } \\
\text { to reduce neurological damage after TRM. }\end{array}$ & $\begin{array}{l}\text { Treatment with Methylprednisolone optimizes neurological } \\
\text { recovery after TRM when used within the first } 8 \text { hours after } \\
\text { injury. }\end{array}$ \\
\hline $\begin{array}{l}\text { Zhang Y, Mamun AA, Yuan Y, Lu Q, Xiong J, Yang S, et al / Emerging } \\
\text { therapies for acute traumatic spinal cord injury / } 2021\end{array}$ & Literature review & $\begin{array}{l}\text { To evaluate clinical applications of naloxone, } \\
\text { tirilazad, and nimodipino, in acute spinal cord } \\
\text { trauma, in relation to neuroprotective effects. }\end{array}$ & $\begin{array}{l}\text { Despite the neuroprotective effects of naloxone, tirilazad and } \\
\text { nimodipine in animal studies, comparative clinical trials did } \\
\text { not show differences in motor recovery after spinal cord } \\
\text { injury. }\end{array}$ \\
\hline $\begin{array}{l}\text { Torres BBJ, Martins BC, Silva CMO, Lavor MSL, Coelho S, Siano GF, } \\
\text { et al / Dantrolene and mesenchymal stem cells promote functional } \\
\text { improvement in Wistar rats with acute spinal trauma / } 2018\end{array}$ & $\begin{array}{lll}\text { experimental } & \text { study } \\
\text { animals }\end{array}$ & $\begin{array}{l}\text { Evaluate the effects of dantrolene and mesenchymal } \\
\text { stem cell therapies on neurological recovery after } \\
\text { acute spinal cord injury in rats }\end{array}$ & $\begin{array}{l}\text { The experiment demonstrated the neuroprotective effects of } \\
\text { isolated and combined therapies with dantrolene and } \\
\text { mesenchymal stem cells through the early initiation of } \\
\text { neurological and functional recovery in animals soon after } \\
\text { acute spinal cord trauma compared to animals using } \\
\text { placebo. There is a lack of clinical trials in humans. }\end{array}$ \\
\hline $\begin{array}{l}\text { Jensen SK, Michaels NJ, Ilyntskyy S, Keough MB, Kovalchuk O, Yong } \\
\text { VW/ Multimodal Enhancement of Remyelination by Exercise with a } \\
\text { Pivotal Role for Oligodendroglial PGCla/ } 2018 \text {. }\end{array}$ & $\begin{array}{l}\text { experimental study in } \\
\text { animals }\end{array}$ & $\begin{array}{l}\text { Integrate the use of the remyelinating drug, } \\
\text { clemastine, with the practice of physical activities in } \\
\text { the recovery of degenerative lesions of the nervous } \\
\text { system }\end{array}$ & $\begin{array}{l}\text { The integrative remyelination process with medications and } \\
\text { physical activity provides a better response in the multimodal } \\
\text { mechanism of regeneration than in isolated therapies }\end{array}$ \\
\hline $\begin{array}{l}\text { Kim JW, Ha KY, Molon JN, Kim YH/ Bone Marrow-Derived } \\
\text { Mesenchymal Stem Cell Transplantation for Chronic Spinal Cord Injury } \\
\text { in Rats Comparative Study Between Intralesional and Intravenous } \\
\text { Transplantation/2013 }\end{array}$ & $\begin{array}{l}\text { experimentalstudy } \\
\text { animals }\end{array}$ & $\begin{array}{l}\text { Understand the use of stem cells as a neurotrophic } \\
\text { factor in spinal cord injury therapy }\end{array}$ & $\begin{array}{l}\text { The use of stem cells as a neuroprotective and neurotrophic } \\
\text { agent represents a promising area in the therapy of spinal cord } \\
\text { injuries. However, the approach to this therapy includes } \\
\text { several critical points about its performance. }\end{array}$ \\
\hline $\begin{array}{l}\text { Anjum A, Yazid MD, Daud MF, Idris J, Ng AMH, Naicker AS, et al./ } \\
\text { Spinal Cord Injury: Pathophysiology, Multimolecular Interactions, and } \\
\text { Underlying Recovery Mechanisms/ } 2020\end{array}$ & Literature review & $\begin{array}{l}\text { Review the pathophysiology of spinal cord injury } \\
\text { and correlate it with neural recovery pathways }\end{array}$ & $\begin{array}{l}\text { The available neuroprotective drugs must be combined to } \\
\text { create favorable environmental conditions for the repair } \\
\text { mechanisms }\end{array}$ \\
\hline Bracken MB/ Steroids for acute spinal cord injury/2012 & Literature review & $\begin{array}{l}\text { Review randomized studies on the use of steroids in } \\
\text { acute spinal cord injuries }\end{array}$ & $\begin{array}{l}\text { High-dose methylprednisolone up to eight hours after injury is } \\
\text { the only steroid that has been shown to be effective in a phase } \\
\text { three randomized trial. }\end{array}$ \\
\hline $\begin{array}{l}\text { Ledo DCR, Jardim GdSdA, Salgado DR, Cabral D, Dias DPM, Machado } \\
\text { DdC/ Use of methylprednisolone in the treatment of spinal cord } \\
\text { trauma/2019 }\end{array}$ & Literat & $\begin{array}{l}\text { Evaluate the benefits of methylprednisolone in the } \\
\text { treatment of spinal cord trauma }\end{array}$ & $\begin{array}{l}\text { The use should be discontinued until new studies with a } \\
\text { greater degree of evidence definitively prove its effectiveness }\end{array}$ \\
\hline $\begin{array}{l}\text { Bracken MB, Shepard MJ, Collins WF, Holford TR, Young W, Baskin } \\
\text { DS, et al./ A randomized, controlled trial of methylprednisolone or } \\
\text { naloxone in the treatment of acute spinal-cord injury. Results of the } \\
\text { Second National Acute Spinal Cord Injury Study/ } 1990\end{array}$ & $\begin{array}{lr}\begin{array}{l}\text { Multicenter, } \\
\text { double-blind, }\end{array} & \text { randomized, } \\
\text { controlled study } & \text { placebo- }\end{array}$ & $\begin{array}{l}\text { Evaluate the use of methylprednisolone and } \\
\text { naloxone in patients with acute spinal cord injury }\end{array}$ & $\begin{array}{l}\text { The application of methylprednisolone aids neurological } \\
\text { recovery if administered within the first eight hours and } \\
\text { naloxone does not aid neurological recovery after acute spinal } \\
\text { cord injury }\end{array}$ \\
\hline $\begin{array}{l}\text { Nagoshi N, Nakashima H, Fehlings MG/ Riluzole as a neuroprotective } \\
\text { drug for a spinal cord injury: from bench to bedside/ } 2015\end{array}$ & Literature review & $\begin{array}{l}\text { Review the literature on preclinical evidence and } \\
\text { emerging clinical data on the use of riluzole in the } \\
\text { treatment of acute spinal cord injury }\end{array}$ & $\begin{array}{l}\text { Riluzole proved to be a drug with a promising future for the } \\
\text { treatment of acute spinal cord injury, but its effects should be } \\
\text { addressed in multicenter studies }\end{array}$ \\
\hline $\begin{array}{l}\text { Srinivas S, Wali AR, Pham MH/ Efficacy of riluzole in the treatment of } \\
\text { spinal cord injury: a systematic review of the literature/ } 2019\end{array}$ & Literature review & $\begin{array}{l}\text { Promote understanding of the effects of riluzole in } \\
\text { spinal cord injury }\end{array}$ & $\begin{array}{l}\text { Animal and human studies demonstrate the efficacy of riluzole } \\
\text { as a neuroprotective drug in cases of spinal cord injury }\end{array}$ \\
\hline $\begin{array}{l}\text { Meshkini A, Salehpour F, Aghazadeh J, Mirzaei F, Alavi SAN/ Riluzole } \\
\text { Can Improve Sensory and Motor Function in Patients with Acute Spinal } \\
\text { Cord Injury/ } 2018\end{array}$ & clinical trial & $\begin{array}{l}\text { To investigate the effect of riluzole in patients with } \\
\text { spinal cord injury regarding the improvement of } \\
\text { sensitivity and motor function }\end{array}$ & $\begin{array}{l}\text { Improved sensitivity, motor function and decreased pain in the } \\
\text { group treated with riluzole for } 6 \text { months. }\end{array}$ \\
\hline $\begin{array}{l}\text { Zhou KL, Chen DH, Jin HM, Wu K, Wang XY, Xu HZ, et al. / Effects of } \\
\text { Calcitriol on Experimental Spinal Cord Injury in Rats/ } 2016\end{array}$ & animal study & $\begin{array}{l}\text { Evaluate the effects of calcitriol on the process of } \\
\text { apoptosis, oxidative stress, autophagy and } \\
\text { locomotor recovery after spinal anesthesia in rats }\end{array}$ & $\begin{array}{l}\text { Calcitriol helps promote locomotor recovery, reduces } \\
\text { oxidative stress, apoptosis and autophagy }\end{array}$ \\
\hline
\end{tabular}




\begin{tabular}{|c|c|c|c|}
\hline $\begin{array}{l}\text { Gueye Y, Marqueste T, Maurel F, Khrestchatisky M, Decherchi P, Feron } \\
\text { F / Cholecalciferol (Vitamin D3) Improves Functional Recovery when } \\
\text { Delivered During the Acute Phase After a Spinal Cord Trauma/ } 2015\end{array}$ & $\begin{array}{lll}\text { experimental } & \text { study } & \text { in } \\
\text { animals }\end{array}$ & $\begin{array}{l}\text { Analyze the effects of vitamin D in the case of nerve } \\
\text { damage }\end{array}$ & $\begin{array}{l}\text { Puts vitamin D as a candidate to be tested in clinical trials for } \\
\text { the treatment of para/tetraplegia soon after injury }\end{array}$ \\
\hline $\begin{array}{l}\text { Aminmansour B, Asnaashari A, Rezvani M, ghaffarpasand F, Noorian } \\
\text { SMA, Saboori M, et al. / Effects of Progesterone and Vitamin D on } \\
\text { Outcome of Patients with Acute Traumatic Spinal Cord Injury; a } \\
\text { Randomized, Double-blind, Placebo Controlled Study/ } 2016\end{array}$ & randomized clinical trial & $\begin{array}{l}\text { To analyze the effects of progesterone and vitamin } \\
\text { D in patients with acute traumatic spinal cord } \\
\text { injuries }\end{array}$ & $\begin{array}{l}\text { Treatment with progesterone and vitamin } \mathrm{D} \text { in the acute phase } \\
\text { of traumatic spinal cord injury is associated with improved } \\
\text { functional recovery of the patient }\end{array}$ \\
\hline $\begin{array}{l}\text { Zhong L, Zhang H, Ding ZF, Li J, Lv JW, Pan ZJ, et al. / Erythropoietin- } \\
\text { Induced Autophagy Protects Against Spinal Cord Injury and Improves } \\
\text { Neurological Function via the Extracellular-Regulated Protein Kinase } \\
\text { Signaling Pathway/2020 }\end{array}$ & $\begin{array}{l}\text { experimental } \\
\text { animals }\end{array}$ & $\begin{array}{l}\text { Explore the molecular mechanism through which } \\
\text { erythropoietin has a neuroprotective effect in rats } \\
\text { after spinal cord injury }\end{array}$ & 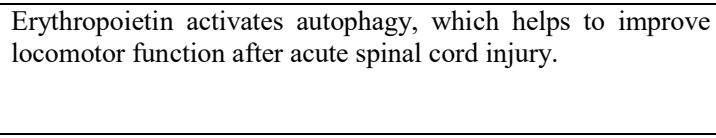 \\
\hline $\begin{array}{l}\text { Marcon RM, Cristante AF, Filho TEPdB, Ferreira R, Santos GBD / } \\
\text { Effects of ganglioside G(M1) and erythropoietin on spinal cord in rats: } \\
\text { functional and histological evaluations/ } 2016\end{array}$ & $\begin{array}{l}\text { experimental study } \\
\text { animals }\end{array}$ & $\begin{array}{l}\text { s of } \\
\text { pinal }\end{array}$ & notor \\
\hline $\begin{array}{l}\text { Alibai E, Zand F, Rahimi A, Rezaianzadeh A / Erythropoietin plus } \\
\text { methylprednisolone or methylprednisolone }\end{array}$ & $\mathrm{d}$ clinical trial & $\begin{array}{l}\text { Compare the use of methylprednisolone alone with } \\
\text { recombinant erythropoietin and methylprednisolone } \\
\text { together in terms of neurological improvement in } \\
\text { patients after spinal cord injury }\end{array}$ & $\begin{array}{l}\text { Recombinant erythropoietin and methylprednisolone may be } \\
\text { more effective than methylprednisolone alone when applied } \\
\text { within } 6 \text { hours of the traumatic injury }\end{array}$ \\
\hline $\begin{array}{l}\text { Lei F, He W, Tian X, Zhou Q, Zheng L, Kang J, et al/ GSK-3 Inhibitor } \\
\text { Promotes Neuronal Cell Regeneration and Functional Recovery in a Rat } \\
\text { Model of Spinal Cord Injury/ } 2019\end{array}$ & $\begin{array}{l}\text { experimental } \\
\text { animals }\end{array}$ & $\begin{array}{l}\text { To analyze the effect of inhibition of the glycogen } \\
\text { synthase kinase } 3 \text { (GSK-3) receptor on neuronal } \\
\text { regeneration. }\end{array}$ & $\begin{array}{l}\text { After the use of the drug TDZD-8, a GSK-3 inhibitor, there } \\
\text { was a reduction in neuronal apoptosis, an increase in the } \\
\text { neuroplasticity protein (GAP-43) and functional improvement } \\
\text { in the limb affected by the injury. }\end{array}$ \\
\hline
\end{tabular}

in neuroregeneration and protection and in immunomodulation. Cell therapy has a mechanism of action that depends on the cell origin. Neural stem cells (NSCs) act by reducing neutrophils, macrophages and pro-inflammatory cytokines, such as IL-1, IL-6 and IL-12, thus promoting recovery of locomotor and sensory functions. Olfactory sheath stem cells (OECs) reduce the size of the glia scar and increase the number of neurofilaments, acting in brain recovery and protection. Due to these characteristics, stem cells are targets of pre-clinical and in vitro assays that demonstrate positive effects in the therapy of spinal cord injuries. Thus, post-spinal trauma intervention has a wide therapeutic scope, be it more conservative or innovative, such as the use of stem cells. ${ }^{16,17,18}$

Vitamin D, progesterone and erythropoietin: It has long been known that Vitamin D acts not only in bone metabolism, but also in neuroprotection. It is able to reduce neurotoxicity by reducing apoptosis, in addition to reducing oxidative stress. Because of this, vitamin D is the target of preclinical trials that demonstrate a positive effect on spinal cord injury. Still, in a clinical trial carried out in 2016, the use of vitamin D associated with progesterone was able to improve the outcome in patients with SCI without any adverse effects being detected. ${ }^{1920.621}$ Erythropoietin is a glycoprotein naturally present in the human body known mainly for its action of stimulating the proliferation of erythroblast precursors. However, in recent years, several studies have been carried out to prove its neuroprotective effects, including in acute spinal cord injury of traumatic origin. One study showe that recombinant human erythropoietin (EPO $\mathrm{hr}$ ) was able to protect rat nervous tissue from secondary injury after trauma by stimulating cellular autophagy. Another study demonstrated the regenerative effect on axonal regeneration and also the effect of inhibiting the loss of neuronal motor function in rats. 22.2
In addition, a systematic review analyzed the outcome of two randomized controlled trials that used hr EPO after TRM. The first concluded that the use of EPO $\mathrm{hr}$ as a neuroprotector has a greater chance of achieving therapeutic success than the use of MP. The second showed that its association with MP had a more effective action than EPO rh used in monotherapy. ${ }^{62425}$

Caspase Inhibitors: Apoptotic pathways arise from the stimulation of caspases, which play an important role in programmed cell death. A wide variety of intracellular and extracellular factors can participate in this process, which include biochemical chain reactions and cytokine complexes. From there, there are two ways. The extrinsic pathway is the receptor-initiated death pathway that, when activated, recruit and activate caspases 8 and 10 and generate pro-caspase- 3 , which is necessary for the conversion of caspase 3. Although they follow different paths, the pathway Intrinsic (mitochondrial pathway) is similar to extrinsic in that it includes the activation of caspase 3 in it process, which regulates cell death. In addition, both are controlled by protein activities, such as glycogen synthase kinase-3 (GSK3) which is a multifunctional serine/threonine kinase that participates in the process of limiting glycogen kinase synthesis rates, B-2 cell lymphoma ( Bcl-2), cyclin-dependent kinases (CDKs), MAPKs and others. ${ }^{226}$ Proteins serve as a link between pathways, and normally pro-apoptotic and anti-apoptotic proteins are in balance. However, if there is an injury, this balance is disrupted generating a promotion of $\mathrm{BH} 3$ interaction domain death agonist proteins (Bid). These Bid proteins interact with Bax and Bak proteins, which also interact with anti-apoptotic proteins Bcl-2 and Bcl-XL. By forming complexes, they delay the onset of caspase 9, which plays an important role in the intrinsic pathway that starts with the release of cytochrome $C$ that causes the recruitment of apoptotic protease activating factor-1 (APAF-1) and of pro-caspases- 9 thus forming apoptosomes, whose regulation causes caspases 9 to convert to caspases 3 and generate cell death. 
Research shows that the apoptosis processes lasted more than three weeks in the TRM, which leads to secondary damage to human tissues with progressive degeneration of the spinal cord. ${ }^{226}$ Regarding drugs of each class, there are Z-DEVD-Fmk, which are selective caspase-3 inhibitors that have anti-inflammatory activity. This drug blocks cytokine synthesis and apoptosis, which leads to reduced ischemia, restoration of locomotor activity, decreased tissue degeneration and increased neuroprotection. However, despite these actions, it is observed that they only temporarily improve neuronal function, and their isolated use is not therapeutically successful. wo

\section{CONCLUSION}

It is concluded that research aimed at acute spinal cord injury of traumatic origin faces several obstacles that hinder the evolution of therapy with neuroprotective agents and its application in clinical practice. The heterogeneity of presentations and evolutions of spinal cord trauma emerges as the main difficulty in this regard, delaying the ability to obtain effective research on the role of neuroprotective agents on the injury. Furthermore, the lack of techniques that demonstrate neuronal preservation and the need for more sensitive prognostic predictors also inhibit advances in research on neuroprotective therapies. Nevertheless, pre-clinical studies involving the use of neuroprotective agents as a potential treatment for acute traumatic spinal cord injury are promising and show the positive effects of these therapies, including several classes, from drugs used in other diseases such as anti- inflammatory drugs, ion channel blockers and neurotransmitter agonists, even newer drugs such as cellular and genetic agents. However, there are still few pre-clinical studies that evolve into clinical trials, which limits the use of neuroprotective therapies in clinical practice. However, most clinical trials reveal a promising scenario by concluding that better outcomes were achieved with the experimental use of these therapies. Thus, there is a need to improve research methods related to the management of traumatic acute spinal cord injury and to bring the knowledge acquired in the laboratory to clinical practice, aiming at better prognosis for these patients.

\section{REFERENCES}

Alibai E, Zand F, Rahimi A, Rezaianzadeh A. Erythropoietin plus methylprednisolone or methylprednisolone Acta Medica Iranica. 2014; 52(4)

Aminmansour B, Asnaashari A, Rezvani M, ghaffarpasand F, Noorian SMA, Saboori M, et al. Effects of Progesterone and Vitamin D on Outcome of Patients with Acute Traumatic Spinal Cord Injury; a Randomized, Double-blind, Placebo Controlled Study. J Spinal Cord Med. 2016 May: p. 272-280.

Anjum A, Yazid MD, Daud MF, Idris J, Ng AMH, Naicker AS, et al. Spinal Cord Injury: Pathophysiology, Multimolecular Interactions, and Underlying Recovery Mechanisms. Pub Med.gov. 2020 October.

Bracken MB, Shepard MJ, Collins WF, Holford TR, Young W, Baskin DS, et al. A randomized, controlled trial of methylprednisolone or naloxone in the treatment of acute spinal-cord injury. Results of the Second National Acute Spinal Cord Injury Study. Pub Med.gov. 1990 May.

Bracken MB, Shepard MJ, WFC Jr, Holford TR, Baskin DS, Eisenberg HM, et al. Methylprednisolone or naloxone treatment after acute spinal cord injury: 1-year follow-up data. Results of the second National Acute Spinal Cord Injury Study. PubMed.gov. 1992 January.

Bracken MB. Steroids for acute spinal cord injury. PubMed.gov. 2012 January.

Campos CFd, Carvalho Md. Riluzole-induced recurrent pancreatitis. PubMed.gov. 2017 November.

Costa DD, Beghi E, Carignano P, Pagliacci C, Faccioli F, Pupillo E, et al. Tolerability and efficacy of erythropoietin (EPO) treatment in traumatic spinal cord injury: a preliminary randomized comparative trial vs. methylprednisolone (MP). PubMed.gov.

\section{September.}

Duncan LD, Browser A, Kondo Y, JF Curlee J, Shultz RD. Extensive Remyelination of the CNS Leads to Functional Recovery. Proceedings of the National Academy of Sciences of the United States of America. 2009 April.

Gueye Y, Marquis T, Maurel F, Khrestchatisky M, Decherchi P, Feron F. Cholecalciferol (Vitamin D3) Improves Functional Recovery when Delivered During the Acute Phase After a Spinal Cord Trauma. J. Steroid Biochem Mol Biol. 2015 November: p. 23-31

Jensen SK, Michaels NJ, Ilyntskyy S, Keough MB, Kovalchuk O, Yong VW. Multimodal Enhancement of Remyelination by Exercise with a Pivotal Role for Oligodendroglial PGC1a. The Cell Press Journal. 2018 September: p. p3167-3179

Joaquim AF, Daniel JW, Schroeder GD, Vaccaro AR. Neuroprotective Agents as an Adjuvant Treatment in Patients With Acute Spinal Cord Injuries: A Qualitative Systematic Review of Randomized Trials. Pub Med.gov. 2020 March.

Kim JW, Ha KY, Molon JN, Kim YH. Bone Marrow-Derived Mesenchymal Stem Cell Transplantation for Chronic Spinal Cord Injury in Rats Comparative Study Between Intralesional and Intravenous Transplantation. Spine. 2013 September: p. E1065-E1074

Ledo DCR, Jardim GdSdA, Salgado DR, Cabral D, Dias DPM, Machado DdC. Use of methylprednisolone in the treatment of spinal cord trauma. UNIFESO Medicine Notebooks. 2019; 2(3).

Lei F, He W, Tian X, Zhou Q, Zheng L, Kang J, et al. GSK-3 Inhibitor Promotes Neuronal Cell Regeneration and Functional Recovery in a Rat Model of Spinal Cord Injury. BioMed Research International. 2019 August; 2019.

Marcon RM, Cristante AF, Son TEPdB, Ferreira R, Santos GBD. Effects of ganglioside G(M1) and erythropoietin on spinal cord lesions in rats: functional and histological evaluations. PubMed.gov. 2016 July.

Meshkini A, Salehpour F, Aghazadeh J, Mirzaei F, Alavi SAN. Riluzole Can Improve Sensory and Motor Function in Patients with Acute Spinal Cord Injury. PubMed.gov. 2018 September.

Nagoshi N, Nakashima H, Fehlings MG. Riluzole as a neuroprotective drug for a spinal cord injury: from bench to bedside. PebMed.gov. 2015 April.

Oliveira KMd, Lavor MSL, Fukushima FB, Caldeira FC, Melo EG. Perspectives on the application of voltage-dependent calcium channel blocking conotoxins in spinal cord trauma. Scielo 2014 March.

Paula MRd, Santos Kd, Batista MAS, Gonçalves RCM, Reis SdS The importance of the team's role in pre-hospital care (aph) to the suspected victim of spinal cord trauma. Brazilian Journal of Development. 2020 December; 6(12).

Srinivas S, Wali AR, Pham MH. Efficacy of riluzole in the treatment of spinal cord injury: a systematic review of the literature. PubMed.gov. 2019 March.

Torres BBJ, Martins BC, Silva CMO, Lavor MSL, Coelho S, Siano GF, et al. Dantrolene and mesenchymal stem cells promote functional improvement in Wistar rats with acute spinal trauma. Scielo 2018 April.

Zhang Y, Mamun AA, Yuan Y, Lu Q, Xiong J, Yang S, et al. Acute spinal cord injury: Pathophysiology and pharmacological intervention (Review). PubMed.gov. 2021 June.

Zhang Y, Mamun AA, Yuan Y, Lu Q, Xiong J, Yang S, et al. Emerging therapies for acute traumatic spinal cord injury. Pub Med.gov. 2021 June.

Zhong L, Zhang H, Ding ZF, Li J, Lv JW, Pan ZJ, et al. Erythropoietin-Induced Autophagy Protects Against Spinal Cord Injury and Improves Neurological Function via the ExtracellularRegulated Protein Kinase Signaling Pathway. PubMed.gov. 2020 October.

Zhou KL, Chen DH, Jin HM, Wu K, Wang XY, Xu HZ, et al. Effects of Calcitriol on Experimental Spinal Cord Injury in Rats. National Center for Biotechnology Information. 2016 January. 